\title{
NOTE ON THE FATE OF CALCIUM CYANAMIDE IN THE SOIL.
}

\author{
BY S. F. ASHBY, B.Sc., \\ Carnegie Research Scholar, Rothamsted Experiment Station.
}

The experiments described below have been carried out to confirm some results obtained by F. Löhnis', who made it appear highly probable that soil bacteria were concerned in rendering calcium cyanamide assimilable for crops. It had been supposed that the reaction of calcium cyanamide in the soil was a purely cbemical one ${ }^{2}$. The material used was taken from a supply of "Kalkstickstoff" received at the Rothamsted Experimental Station from the "Cyanid Gesellschaft" of Berlin early this year. Nitrogen determinations by the Kjeldahl method showed the crude fertiliser to contain 20.3 per cent. nitrogen, equal to 58 per cent. pure calcium cyanamide. In order to obtain the action of soil organisms on the cyanamide a culture solution of the following composition was prepared :-

\begin{tabular}{|c|c|}
\hline "Kalkstickstoff" & $1 \cdot 0$ gram \\
\hline Monopotassium phosphate & 0.5 \\
\hline Cryst. magnesium sulphate & 10 \\
\hline Sodium chloride & 0.2 \\
\hline Dextrose.......... & $1 \cdot 0$ \\
\hline Distil & $T$ \\
\hline
\end{tabular}

Erlenmeyer flasks of 250 c.c. capacity each received 75 c.c. of the solution and 1 gram of fresh soil taken from arable land at a depth of $10 \mathrm{~cm}$. Five of these were placed in the incubator without further treatment, two others were boiled for three minutes to secure sterilisation, and another pair to which no soil was added were treated with a few drops of a concentrated corrosive sublimate solution before incubation.

1 Centralbl. f. Bakt. Abt. II. Bd. 14, p. 87, 1905.

2 See this vol., p. 146. 
Two control solutions not previously boiled gave by distillation with magnesia a mean of $70 \mathrm{mg}$. nitrogen, and another pair after boiling for three minutes yielded by distillation a mean of $1 \cdot 2 \mathrm{mgs}$. nitrogen. The total nitrogen found by Kjeldahl's method was $15.0 \mathrm{mgs}$. in 75 c.c. solution and $1.4 \mathrm{mgs}$. in 1 gram of the soil. The flasks were incubated at $25^{\circ} \mathrm{C}$. for 43 days, and were then examined for ammonia and total nitrogen. The two solutions inoculated with soil and boiled developed a surface film after a few days, and can consequently only be regarded as partially sterilised. The results of a qualitative examination are given in Table I.

\section{TABLE I.}

Incubation period at $25^{\circ}$ : March 15-April 27, 43 days.

Iridescent surface film and deposit in all flasks seeded with soil.

Flasks containing corrosive sublimate showed no growth.

No solution showed either nitrite or nitrate.

\begin{tabular}{|c|c|c|}
\hline Culture & Ammonia by Nessler & Reaction \\
\hline 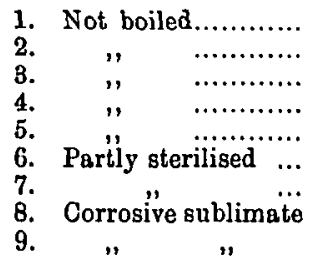 & $\begin{array}{l}\text { abundant } \\
\text { faint } \\
\text { abundant } \\
\text { moderate } \\
\text { faint } \\
\text { " } \\
\text { none } \\
\text { " }\end{array}$ & $\begin{array}{c}\text { strongly alkaline } \\
\text { weakly alkaline } \\
\text { strongly alkaline } \\
\text { less strongly alkaline } \\
\text { moderately alkaline } \\
\text { weakly alkaline } \\
\text { ", neutral" } \\
\text {," }\end{array}$ \\
\hline
\end{tabular}

The results of the determinations of ammonia by distillation with magnesia and of the nitrogen in the residue therefrom by Kjeldahl's method are shown in Table II.

Culture (5) was not distilled but was tested for sugar with Fehling's solution, and gave a negative result. It is evident that the alkalinity of all the incubated solutions was due to free ammonia, so that it is not surprising that a considerable loss of nitrogen by volatilisation took place. In the solutions to which corrosive sublimate had been added there was practically no formation of ammonia, indicating that a sterile calcium cyanamide solution can be kept for a long time without any notable reaction occurring with the water present. It is reasonable to infer from this, that the formation of ammonia from cyanamide in the soil can be due in only a very minor degree to a purely chemical process. On the other hand where soil organisms were active as much as 80 per cent. of cyanamide nitrogen was converted to ammonia. 
360 Note on the Fate of Calcium Cyanamide in the Soil

TABLE II.

\begin{tabular}{|c|c|c|c|c|c|c|c|}
\hline Solution & 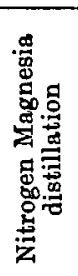 & 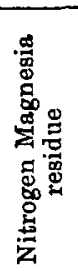 & 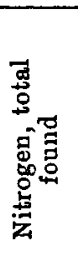 & 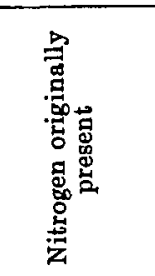 & 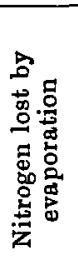 & 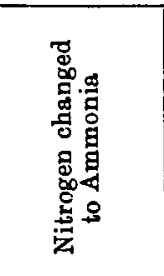 & 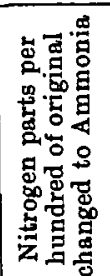 \\
\hline 1. Not boiled. & $\underset{7 \cdot 40}{\mathrm{mgs} .}$ & $\begin{array}{l}\text { mgs. } \\
4 \cdot 19\end{array}$ & $\begin{array}{l}\text { mgs. } \\
11 \cdot 59\end{array}$ & $\begin{array}{c}\text { mggs. } \\
\left\{\begin{array}{c}15 \cdot 0+1 \cdot 4 \\
\text { (soil) }\end{array}\right\}\end{array}$ & $\begin{array}{l}\text { mgs. } \\
4 \cdot 81\end{array}$ & $\begin{array}{c}\text { mgs. } \\
\left\{\begin{array}{c}12 \cdot 21-\cdot 70 \\
=11 \cdot 51\end{array}\right\}\end{array}$ & $\begin{array}{c}\text { per cent. } \\
80.5\end{array}$ \\
\hline 2. $"$, & 1.82 & lost & - & $16 \cdot 4$ & - & - & - \\
\hline 3. ", & $7 \cdot 26$ & $5 \cdot 59$ & $12 \cdot 85$ & $16 \cdot 4$ & $3 \cdot 55$ & $10 \cdot 11$ & $70 \cdot 7$ \\
\hline 4. , & $4 \cdot 47$ & 10.06 & $14 \cdot 53$ & $16 \cdot 4$ & $1 \cdot 87$ & $5 \cdot 64$ & $40 \cdot 0$ \\
\hline $\left.\begin{array}{l}\text { 6. Boiled, partly } \\
\text { sterilised... }\end{array}\right\}$ & 3:35 & $9 \cdot 22$ & 12.57 & 16.4 & $3 \cdot 83$ & $\left\{\begin{array}{c}7 \cdot 18-1 \cdot 2 \\
=5 \cdot 98\end{array}\right\}$ & $39 \cdot 9$ \\
\hline 7. $"$ & $2 \cdot 65$ & $11 \cdot 60$ & $14 \cdot 25$ & $16 \cdot 4$ & $2 \cdot 15$ & $3 \cdot 60$ & $24 \cdot 0$ \\
\hline $\begin{array}{l}\text { 8. Corrosive sub- } \\
\text { limate sterilised }\end{array}$ & 0.70 & 13.97 & $14 \cdot 67$ & $15 \cdot 0$ & 0.33 & 0.33 & $2 \cdot 2$ \\
\hline 9. & $0 \cdot 70$ & $14 \cdot 04$ & $14 \cdot 74$ & $15 \cdot 0$ & 0.26 & $0 \cdot 26$ & $1 \cdot 7$ \\
\hline
\end{tabular}

Löhnis in a further communication ${ }^{1}$ has shown that two organisms (B. Kirchneri and B. lipsiense), isolated by him from cyanamide solutions seeded with soil, can ammonify that fertiliser very rapidly. They act very feebly on urea and peptone, while the bacteria which rapidly ammonify urea and peptone show little or no power to attack calcium cyanamide.

It may be remarked in conclusion that calcium cyanamide $\mathrm{CaCN}_{2}$ contained in "Kalkstickstoff" is insoluble in water but reacts with the latter to form a soluble salt and calcium hydrate which renders the freshly prepared solution alkaline:

$$
2 \mathrm{CaCN}_{2}+2 \mathrm{H}_{2} \mathrm{O}=\mathrm{CaH}_{2} \mathrm{C}_{2} \mathrm{~N}_{4}+\mathrm{Ca}(\mathrm{OH})_{2} \text {. }
$$

The author was able, by precipitating all the lime with ammonium oxalate, evaporating the filtrate to dryness, extracting with a little strong alcohol and allowing the latter to evaporate at the ordinary temperature, to obtain yellow crystalline plates which yielded on analysis $62 \cdot 70$ per cent. nitrogen and agreed with the description given for dicyandiamide (Beilstein, Organische Chemie) which contains when quite pure 66.60 per cent. nitrogen. A solution of calcium cyanamide after long standing goes over into dicyandiamide which yields no ammonia by distillation with magnesia.

1 Centralbl. f. Bakt. I1. 14, p. 389. 